\title{
The Da'i (Muslim Preachers) And So- cial Change Challenges: A Study Of Da'i Professionalism In Dumai, Riau
}

\author{
DOI 10.18196/AIIJIS.2020.0113.58-81
}

\section{TONI HARTONO', MASDUKI' ${ }^{2}$ IMRON ROSIDI' ${ }^{3}$, PIPIR ROMADI ${ }^{4}$}

Faculty of Da'wah and Communication, UIN Sultan Syarif Kasim Riau'1,2,3,4

Correspondence Email: toni.hartono@uin-suska.ac.id

\begin{abstract}
The development of information technology is one of the causes of social changes that occur and currently shows the complexity of the problems faced by people and preachers. This requires professional preachers to be able to become agents of change. This was then responded to by the PMD in Dumai. This article examines the preacher's professionalism in the dynamics of social change in the Dumai Muballigh (Muslim Preacher Association/ PMD). This study does not focus on whether the efforts done by the PMD to improve the professionalism of Muslim preachers in Dumai are successful or not. This article focuses on efforts done by the PMD to improve their professionalism. In preaching, the development of preaching resources is emphasized in various aspects such as material, mental, skills, knowledge, and psychic. This article used observation and interviews to collect data. The results showed that the effort to create professional preachers in the PMD is doing human resource development through mudhakarah (discussion on Islamic Issues) and preaching guidance to strengthen science and skills, training and use of IT (Information Technology) as a form of transformation, conducting preaching certification as an effort to assess and qualify the quality of preachers' abilities, improving education levels through further education cooperation agreements among preachers and companies, universities and government, and the development of contemporary preaching material through the study of books, and hadith.
\end{abstract}

\section{ABSTRAK}

Perkembangan teknologi informasi merupakan salah satu penyebab terjadinya perubahan sosial yang terjadi dan saat ini menunjukkan kompleksitas permasalahan yang dihadapi oleh umat dan dai. Ini membutuhkan da'i yang profesional untuk bisa menjadi agen perubahan. Hal tersebut kemudian ditanggapi oleh Persatuan Muballigh Dumai (PMD) di Dumai. Artikel ini mengkaji profesionalisme da'i dalam dinamika perubahan sosial di PMD. Studi ini tidak fokus pada apakah upaya yang 
dilakukan oleh PMD untuk meningkatkan profesionalisme da'i Dumai berhasil atau tidak. Artikel ini berfokus pada upaya yang dilakukan oleh PMD untuk meningkatkan profesionalisme mereka. Dalam dakwah, pengembangan sumber daya da'i ditekankan pada beragam aspek seperti materi, mental, skill, pengetahuan, dan psikis. Hasil penelitian menunjukkan bahwa upaya menciptakan da'i profesional yang dilakukan PMD adalah pada pengembagan SDM melalui mudhakarah dan bimbingan dakwah untuk memperkuat keilmuan dan skill, pelatihan dan pemanfaatan IT sebagai bentuk transformasi perubahan yang terjadi, melakukan sertifikasi da'i sebagai upaya penilaian dan kualifikasi kualitas kemampuan da'i, peningkatan jenjang pendidikan melalui perjanjian kerjasama pendidikan lanjutan bagi da'i dengan perusahaan, perguruan tinggi dan pemerintah, dan pengembangan materi dakwah kekinian melalui kajian kitab, dan hadis.

Keywords: professional, preachers, social change, propaganda, PMD

\section{INTRODUCTION}

Along with the development and change of time, especially in today's digital era, Islamic da'wah (mission) experiences complexity related to the problems of human life. As a religion, Islam provides a solution to the problems faced by the people. One of the solutions to the problem of Muslims is depending on the role of the preachers. It is about the extent to which the preacher's insight in seeing social reality. As a result, the preacher is able to understand the da'wah map related to diverse problems, culture, and character. In such a complex problem, the preacher should be able to play a constructive role in society by considering the socio-historical nature of a community. ${ }^{1}$ Da'wah can be literally meant "call," which then has a broad definition referring to many activities. The broad concept of da'wah, however, is limited in this article. It focuses on the oratory or da'wah bil-lisan. Millie argues that da'wah bil lisan is the authentic da'wah activity because it is a central element of Islamic activities such as tabligh akbar (great preaching), pengajian (study groups), tausiyah (short preaching) and many others. ${ }^{2}$

The challenges of da'wah such as Christianization, ignorance, poverty, the influence of the internet and digitalisation of media, brawls, the emergence of splinter groups in the name of Islam, disharmony, press freedom and uncontrolled and responsible mass media, are a series of examples of the many problems of da'wah (preaching). These become a challenge for preachers to improve their competence and insight and hone their intelligence and creativity to solve public problems. ${ }^{3}$

Along with the development of an increasingly modern and sophisticated era, of course, the object of da'wah receives more attention. The preachers 
can carry out new strategies that are adaptive to synchronize culture with the methods and media used. With the changes in social structure, social strata, and technology culture of the community, the task of preachers to utilize the latest media in conveying the message of preaching is crucial. At present, humans are very dependent on the existence of technology. In spite of all the effects it has caused, people unknowingly gave birth to a new culture related to the use of technology. The reality of the world of da'wah at this time is causing anxiety because of the condition of the structure of society in such a way, not comparable to the expertise of preachers in preaching messages. ${ }^{4}$

In this context, preachers have an essential role as agents of change. They become agents of change in Muslim social life. Since change is sunnatullah (the laws of God), it always happens and impacts everyone. The impact of changes is like two sides of a coin which is interconnected. If the changes are massive and have a negative impact on human life as a whole, an active role of the preacher is needed so that the preacher becomes a stronghold of faith, creed, and worship of the people. For this reason, professional da' $i$ (Muslim preachers) must be prepared in a broad context.

Research related to professionalism by Risdiana ${ }^{5}$ examines the process of developing the role of a preacher so that they can perform optimally with the five criteria. The five criteria are as a communicator, counselor, problem solver, manager, and entrepreneur. Meanwhile, Perdamaian et al. ${ }^{6}$ studied the electronic media-based da'wah strategy by utilizing local radio and television media in Dumai City. Meanwhile, Fahrurrozi, ${ }^{7}$ Annur, ${ }^{8}$ and Arsam $^{9}$ focus more on the certification of preachers. Risdiana ${ }^{10}$ states that a professional preacher must meet at least five criteria, namely: 1) Preacher as a communicator must have the rhetoric ability, basic knowledge of individual and social psychology, and the ability to utilize the media for propaganda activities. 2) Da'i (preacher) as counselors must be able to foster and assist the community, convert, foster religious social organizations, and young people. 3) Da'i, as a problem solver, should be able to enrich data on various kinds of da'wah problems, understand social settings, blend in, and collaborate with religious social organizations. 4) Da'i as managers must be able to lead themselves, become motivators of the Ummah, manage and organize preaching activities, and 5) Da'i as entrepreneurs never give up, and ready to work hard. However, Perdamaian et al. stated the importance of the use of electronic media by the Dumai Preacher Association (PMD), mainly through radio and television, with expert guidance. ${ }^{11}$ Fachrurrozi ${ }^{12}$ empha- 
sizes the importance of standardization efforts in all aspects of religion, especially in aspects of mosque management and religious institutions, under the guidance of the Indonesian Ministry of Religion and Islamic social organizations. However, his findings do not suggest the importance of preacher certification.

Several studies on the da'wah generally do not focus on the importance of local preachers to organize their efforts for the improvement of oral da'wah. The above studies leave a gap in which several local da'i (preachers) in Dumai has organized themselves into an organization called the PMD. This organization was established as an effort to improve its professionalism in preaching or da'wah. Zaini, ${ }^{13}$ for instance, proposes a theoretical analysis of da'wah on television. This study, based on the normative perspective, neglects empirical milieus, which needs in-depth observation and analysis. Basit ${ }^{14}$ also explains about da'wah in this modern era. His study, however, fails to capture the dynamics of local da'wah, which needs empirical study.

The study conducted in the city of Dumai shows the phenomena in other regions in general. However, Dumai, as a metropolitan city in Riau Province, faces significant social dynamism so that constructive and persuasive preaching efforts are needed. One of the efforts made is through increasing professional preachers. The number of preachers registered in the Dumai Muballigh Association (PMD) is about 450 people. ${ }^{15}$ These preachers have joined in several da'wah organizations like the Majelis Da'wah Islamiyah (MDI), Ikatan Kemakmuran Masjid Indonesia (IKMI), and Ikatan Da'i Indonesia (IKADI).

Da'wah institutions and the government of Dumai City are developing in increasing the professionalism and quality of the preaching by the preachers. The vast field of da'wah and increasingly complex challenges prove that the da'wah movement will be more effective and efficient if its implementation is carried out professionally in order to achieve maximum results. Regardless of the preaching activities carried out personally or collectively, the most fundamental thing lies in the quality and moral integrity of the preacher. Preachers' mistakes in conveying religious messages also influence mad'u (the object of da'wah) as recipients of religious messages. In preaching, the preachers should not judge the success of preaching only in terms of quantity and formality, such as the number of mad'u, the number of students, and so on. But it should be more on the quality and impact caused by the da'wah delivered to the community. Therefore, it is necessary to develop the resources of preachers in order to grow the attitudes and profes- 
sional abilities of a preacher in carrying out his missionary duties.

This article is based on the fact that the community as the target of da' wah experiences dissatisfaction with the preachers who carry out their missionary duties. This dissatisfaction is caused by unattractive material, inappropriate methods, and even differences in understanding the da'wah, which may cause conflict in the community. Indeed, a preacher is demanded to be able to overcome conflict rather than trigger conflict. Departing from this fact, this study discusses how to improve the professionalism of the preachers of Dumai City, especially those who are members of the Dumai Preacher Association (PMD) and the efforts made by the preachers so that their preaching is well received by the community. This article contributes to the discussion of Dumai City preachers' professionalism.

\section{$D A^{\prime} W A H$ AND SOCIAL CHANGES}

In the social movement theory proposed by Horton and Hunt, the notion of resource mobilization is known to describe the importance of effective resources to support the social movement goals. ${ }^{16}$ Social change is considered a goal of this social movement. It needs organization and effective efforts. In this context, da'wah should be a social change movement that has succeeded in reforming society as exemplified by the Prophet. To achieve the goals, da'wah then needs an organization which then makes serious efforts to implement the da'wah mission includes various aspects, including strengthening the socio-religious aspects in the form of strengthening the aqidah of the people starting with the construction of the mosque and strengthening the socio-political and socio-economic aspects by implementing zakat orders and prohibiting usury and encouraging work ethics. ${ }^{17}$

The implementation of the da'wah movement needs to face the social changes prevailing in the society. Today, Muslim communities, in particular, are facing increasingly rapid and stretching technological challenges that have an impact on the structure of their lives. This fact forces the preachers to prepare and adjust to social changes ${ }^{18}$ especially related to media digital changes. The community and preachers are not able to avoid the development and changes so that they should be able to adapt to these changes.

It is undeniable that Indonesia and the world are facing very rapid changes in terms of economic, socio-cultural, technological, and social systems. The changes have an impact on the preachers in carrying out their da'wah. Da'wah is expected to foster ummah's (Muslim community) self- 
awareness related to perception, understanding, and perfect awareness of Islam. Islam is a source of values that can substitute strength and motivation. Muslims then should internalize, realize, and actualize these Islamic values in their lives. ${ }^{19}$

Although da'wah emphasizes more on the process, the results or objectives of da' wah are expected to change the Mad'u, including knowledge, understanding, attitudes, and actions concerning aqidah, worship, mu'amalah, and morals. These changes are made possible due to changes in values that are actually shared by mad'u. Da'wah is also a process of social change because changes in value at the individual level can influence the community level as a result of social interaction between individual members of the community. Since preaching is a process of communication and the process of social change, the preaching focusing on oral speech becomes inadequate anymore, especially when the preaching activities are dealing with various social problems and challenges in the current new media era. ${ }^{20}$

Therefore, da'wah also cannot be separated from the process of communication. As a result, da'wah, communication, and social change are integral. Da'wah, without communication, cannot implement the desired targets, namely the positive changes in society. Therefore, preaching as a process of social change plays a role in changing values in society in accordance with the objectives of Islamic da'wah. Thus, the da'wah of Islam (da'i) as an agent of change provides a philosophical basis for "self-existence" in individual, family, and sociocultural dimensions. Therefore, the actualization of da'wah is related to the efforts to organize society continuously in the midst of the dynamics of social change. ${ }^{21}$

The preaching carried out by the preachers is currently increasing in quantity. Recently, preachers use various media such as television, radio, newspapers, magazines, mobile phones, and the internet. With the increasing use of media, the da' wah has positive implications for increasing religious understanding among Muslims. However, this is certainly expected to be directly proportional to the increase in the productivity of the people. To realize that, there is a need to support the da'wah steps that motivate and develop mad'u (object of da'wah) at a more established level both in terms of religious scholarship and the economic sector. As a result, it balances the spiritual and physical needs. ${ }^{22}$

Da'wah is a process of planned social change designed to improve the standard of living of the people, in which it is complementary to social devel- 
opment. Social development is a development approach aimed to improve the quality of human life in a complete manner by meeting human needs that range from physical to social needs, but the most important thing is how to maintain the level of religion as the principal capital in every aspect of life. Therefore, social change is going in a certain direction, so the Islamic da'wah functions to provide the ideal direction and style of society. ${ }^{23}$

\section{THE PROFESSIONALISM OF THE $D A^{\prime} I$}

The word of professionalism comes from a professional, which means a profession that requires a special skill. ${ }^{24}$ Professionalism is " the combination of all qualities that are connected with trained and skilled people"25 Based on this definition, professionalism is central for any profession, including Muslim preachers. This phrase of professionalism of the preacher is then juxtaposed with the term of preacher certification, the legitimacy to the preachers, or standardized echoed by the Indonesian Ulema Council (MUI). The certificate given to the preacher is intended to provide protection and as a guarantee that the preacher does not have a problem. ${ }^{26}$

The MUI, as an official institution appointed by the government, issues the criteria of preachers who gain legitimacy, certification, or standardization as professional preachers by a) having profound religious competence, b) having an insight into national commitment, and c) having moral commitment and experience. ${ }^{27}$ At that time, 200 preachers certified issued by the Ministry of Religious Affairs emerged and later became a controversial phenomenon.

The list of 200 preachers certified by the Ministry of Religion has a negative impact on other preachers. Even Hamdan Zoelva, as Chairman of the Serikat Islam, criticised this case. He regretted the decision issued by the Ministry of Religion of the Republic of Indonesia so that it was as if the preacher who was not included in the list of 200 preachers did not love the Republic of Indonesia and the trouble maker. This phenomenon is actually troubling the community, especially the preacher standardization discourse and preacher certification.

The term of preaching certification was proposed by the Director-General of Islamic Community Guidance of the Ministry of Religious Affairs, Machasin. He said that the certification of preachers was crucial because not all preachers understood Indonesian culture. ${ }^{28}$ The controversy over the preacher standardization and preacher certification discourse takes place between the 
government and a number of groups. On the one hand, the government states that preaching certification and pre-standardization of preachers are vital. Preachers must have competence in the field of religion and not against government regulations, let alone to anti-NKRI and anti-Pancasila. ${ }^{29}$

The discourse on certification and standardization for preachers emerged because of complaints from the public. Some people view that Friday sermons and religious lectures invite religious debates in society, like disseminating the issue of khilafiyah (differences of religious opinions), hate speech, and even against the Pancasila. As a result, this should be prevented by issuing regulations in order that deviations do not become increasingly disturbing. ${ }^{30}$

However, this discourse is not without rejection. There is a number of figures rejecting the existence of preacher certification and preacher standardization. Sodik Mujahid, Deputy Chairperson of Commission VIII DPR $\mathrm{Rl}$ from the Gerindra Faction, rejected the Ministry of Religion's proposal. He considered the standardization of preachers and the preachers' certifications would be a way to limit the sermon. According to him, only preachers who have the certification can preach. Factually, it was also noted that the establishment of preachers and preachers in mosques and mushallas (small mosques to pray) was determined through a meeting of takmir and community leaders. The fact is that there is very little news related to the rejection of preachers and preachers even if there were, only cases such as the rejection of Ustadz Abdul Somad, LC., MA (UAS) on the grounds of being involved in $\mathrm{HTI}$ and radicalism as well as some threats and intimidation from various regions such as Central Java, Malang, Yogyakarta, Solo, Jombang, Kediri, and several other areas in Indonesia. ${ }^{31}$

A Muhammadiyah activist, Mora Harahap, also rejected this discourse. He said that the Ministry of Religious Affairs' plan to certify preachers was considered inappropriate. According to him, this policy will only cause controversy, high sensitivity, and disturbing Muslims. ${ }^{32}$ Currently, a preacher who can deliver his da'wah to the Ummah well is needed, certainly with the scientific competence possessed. The da'wah institutions have also conducted a rigorous selection of preachers.

Zainut Tauhid Sa'adi, gave a response related to the preacher certification discourse. He delivered three conditions as an important proposal for preacher certification. First, the preacher certification program was intended to increase the capacity, capability, and competency of preachers, both in mate- 
rial and methodological aspects. According to Sa'adi, the condition of Indonesian people, in particular, is changing with the rapid development of information technology. This encourages all people to adapt, as well as the preachers who will deliver their da'wah. Second, the program is voluntary and not an obligation. The da'wah program is essentially the right and obligation of every Muslim to carry out religious orders. If the preacher certification is required, it is also feared that there will be an appearance of intervention from the government. Instead, this can be counter-productive. Third, the certification program should ideally be carried out by Islamic organizations or the community, not the government. In this context, the government only acts as a facilitator, thus encouraging community participation and is responsible for preparing qualified preachers from both material and methodological aspects. ${ }^{33}$

It cannot be denied that the profession carried by a preacher is a job that requires knowledge, skills, abilities, expertise, to create a society as expected. ${ }^{34} \mathrm{Amin}^{35}$ proposed that, in the da'wah guidelines compiled by the Indonesian Ulema Council, specifically, the actors of da'wah, including khatib, require 1) Integrity and quality of preachers, 2). Da'i competence. In the context of this study, it can be said that the government is present to guarantee the quality of Friday sermons because there are indications of material that is not in accordance with the Shari'a. For this reason, it is necessary to make criteria for the minimum threshold of competence that must be possessed by a preacher.

\section{DUMAI AND THE PMD}

Dumai is the second metropolitan city after Pekanbaru in Riau province, Indonesia. Dumai City is approximately $188 \mathrm{~km}$ from Pekanbaru, Riau. In historical records, Dumai City is a small village on the east coast of Riau Province that began to squirm into pearls on the coast of Sumatra because it is dealing directly with the Malacca Strait. Administratively, Dumai City before 1999 was in Bengkalis Regency. But, it was separated into the City on April 20, 1999, through Law No. 16 of 1999. ${ }^{36}$

Until now, Dumai has an organization that manages the preaching movement of the preachers, namely the Missionary Association of Dumai (Persatuan Muballigh Dumai, PMD). This religious organization is located at Habiburrahman Mosque, Jn. HR Soebrantas Dumai. Since the establishment of PMD until now, all preaching activities are arranged and scheduled 
online. Friday sermon activities, Ramadan spiritual splash, Eid al-Fitr, Eid alAdha, Isra Mi'jraj of the Prophet Muhammad, Islamic New Year, Prophet Muhammad's Birthday and others are a series of activities scheduled by PMD in a structured and systematic manner. Their da'wah activities accommodate the time, place, theme, title, and preacher who will carry out the da'wah. This certainly has a positive impact on the people of Dumai. ${ }^{37}$

The PMD of Dumai initially conducted da'wah with various media, such as; Da'i voice bulletin, radio, cable TV, and live streaming TV. However, as time goes, the PMD only utilizes two da'wah media through radio and television. PMD propaganda activities and movements through radio and television are evidenced by the collaboration with Ar-Rahman 102.2 FM radio, Dumai Vision, and Dumai TV Documentation. This PMD missionary activity is presented in the form of a live broadcast. In addition, the coverage of preaching activities in the PMD was also consistently broadcast by the television and radio media. ${ }^{38}$

The PMD missionary movement through radio and television is still just ordinary preaching broadcast material. Da'wah, that is packaged by radio and television is a monologic da'wah like the commemoration of religious holidays. Through television and radio, preaching was delivered in the form of PMD preaching activities report, such as preaching cadre training, preaching certification, workshops, mudhakarah, and so on. ${ }^{39}$ Da'wah's collaboration between PMD and Ar-Rahman radio is implemented in the form of live dialogic da'wah on the radio. Da'wah, through the radio, can be packaged dialogically (talking) can also be monologue (a preacher alone appears in the radio channel through radio can be heard directly by viewers through electromagnetic waves.

As a movement organization, the PMD is a neutral da'wah organization. Its members are not exclusively categorized into several terms and organizations. It is not a salafi da'wah organization. It is also not linked to mainstream Islamic organizations like Nahdlatul Ulama and Muhammadiyah. Therefore, the PMD is accepted among Muslims in Dumai because of its inclusive character and its role as an umbrella organization. It is different from IKMI (Ikatan Masjid Indonesia or Indonesian Mosque Association), for instance, which is linked to PKS (Partai Keadilan Sejahtera) or MDI (Majelis Da'wah Islamiyah) which is associated with Golkar Party. 


\section{EFFORTS TO IMPROVE THE PROFESSIONALISM OF THE PMD PREACHER}

Da'i professionalism in da'wah is paramount in this era. Da'wah is realized as an effort to transform the values of goodness. Da'wah should be done professionally, dynamically, and flexibly. The preachers are also required to have a high vision and moral values, as well as to be a figure whose behavior can be emulated by anyone. As preachers are required to have skills, skills, and knowledge, to achieve this position, educational institutions and da'wah organizations are needed to prepare professional preachers. Cooperation, good communication, and ongoing between these institutions is in order to prepare professional da'wah cadres. ${ }^{40}$

Da'i cadres in delivering Islamic teachings are required to have high credibility and integrity. Credibility arises through the role of preachers as agents of change that are innovative, creative, and dynamic to develop a sense of crisis of the preachers. The da'i are required to be responsive, decisive, and wise. They are often used as an example and community reference so that they will always be valued by the people. The people see the preachers as teachers who must be heard and respected. The morality of the preachers must be implemented in social life. ${ }^{41}$

In delivering their da'wah, the preachers are required to have the ability to master a variety of competencies and expertise, both substantive and methodological. Mulkhan puts forward the substantive ability as, "... mastering the teachings of Islam correctly and appropriately, having a good character or having good character, and knowing the development of science. Methodological competence is the ability of a preacher to make preaching plans ranging from preparation, implementation, and evaluation of preaching activities. ${ }^{42}$

The PMD prepares professional preachers through planning. Preaching planning begins with the unification of preachers, which are accommodated by preaching institutions in Dumai, such as IKMI, MDI, and others. The unification of preachers in the same place is intended to facilitate coordination, equalization of perceptions and material, and other technical matters. Coordination is important in the organization of da'wah, especially in terms of preaching schedule, the location where da'wah is held, and the time of preaching. While the equalization of perceptions and material is related to the simplicity of da'wah especially related to khilafiyah issues. 
In planning, the PMD distributes preachers, according to the community, needs thorough online scheduling, as stated by Widodo. ${ }^{43}$ _Online scheduling is intended to facilitate the implementation of da'wah that will be carried out by the preacher. Through the existing application, the preachers can easily access the preaching schedule wherever and whenever. Technology is truly capable of deciding the time and place space associated with many problems faced by humans, including the preachers at the PMD.

The problem of the lack of professional preachers in carrying out their da'wah is a global problem, so it takes maximum effort from various elements, such as academics and practitioners of da'wah. Both of them are expected to be able to develop a formative scientific formulation of da'wah, from classical and modern literature, and through scientific studies starting from empirical experience ${ }^{44} \mathrm{so}$ that the concept of da' wah can be obtained. This can be used as a reference in the implementation of da'wah, especially in dealing with the diversity of Mad'u and the complex da'wah field.

The development of a preacher's expertise does not stop in the area of just being able to speak in public. If you only have that intelligence, then it can not be denied if one day, the preacher can deceive the congregation. This is certainly not wanted by anyone. Therefore, it is necessary to develop the potential of expertise to the preachers to the maximum. Having knowledge of religion is not enough for preachers. The preachers are required to have cross-scientific knowledge and must understand as well as be sensitive to the current problems of the people.

The PMD in carrying out preaching makes careful planning by analyzing the problems faced when preaching. In this context, the PMD preachers preach based on the needs of the community as the object of preaching. As a result, the preaching carried out touches the needs of the community. This is also done by the PMD preachers with the concept of mudhakarah.

The presence of the PMD becomes essential as a basis for developing the professionalism of preachers. The PMD is as a forum to improve the quality and quality of management as well as assessing and evaluating preachers' performance. In addition, the PMD has the role and duty to discipline preachers in order to become an example for the community. The roles and tasks of the PMD are all inseparable parts to increase the professionalism of the preachers. Efforts to improve professionalism are carried out through mudhakarah activities, training for preachers, the use of IT, preacher certification, improvement of education levels, and the development of contemporary 
preaching materials. The six findings are described below:

\section{Mudhakarah}

Mudhakarah or known as the discussion ${ }^{45}$ is an essential activity for preachers in an effort to improve the quality of knowledge and material propaganda. The PMD conducts mudhakarah activities in an effort to update the da'wah material in relation to the present context. Material update through discussion or mudhakarah is vital to be done among the PMD because the situation and condition of the congregation are getting wider sources of information, especially in the millennial era. The PMD adjusting the da'wah material to the conditions of the congregation is a must and is done through mudhakarah activities.

This activity is carried out consistently and continuously. Muzakarrah is done periodically in the weekly and quarterly. It aims to provide a refreshing theme and da'wah material. The mudhakarah is done by bringing da'wah experts from outside the city, such as Ust. H. Abdul Somad, Lc., MA, Dr. H. Mawardi M. Saleh, MA, and Dr. Fahri, M.Ag. These three mudhakarah resource persons shared da'wah material such as about aqidah (theology), fiqh (Islamic Jurisprudence), muamalah (human relationship), and others. This activity is intended to improve the scientific abilities and skills of the Da'i in developing the mission of Islamic da'wah in Dumai City.

Mudhakarah or discussion is done in a relaxed, dynamic, and dialogical manner. Each preacher involved in the discussion activity is given the opportunity to ask the actual problems faced in the da'wah field. With this activity, each preacher will get an overview and solution that can be applied in every da'wah activity. In addition, it also adds scientific insights related to da'wah material that will be delivered to the public.

The material of mudhakarah is always adjusted to the conditions encountered by preachers in the field related to some crucial issues such as khilafiah and differences in the religious understanding of the preachers and pilgrims. This is done with the intention of equalizing perception and understanding so that conflicts do not occur between jama'ah (congregation). The fact is that there are still many khilafiyah problems that occur but can be resolved properly through understanding agreements. Therefore, the mudhakarah is very important for all preachers to address these conditions.

\section{The Training and the Use of IT (Information Technology)}

Community life continues to evolve so that preaching activities must be 
dynamic, innovative, and creative. The dynamics and creativity of da'wah are not only on material that must always be relevant to the needs of the community ( $\mathrm{mad}^{\prime} u$ ), but also on the theory, methodology, and media used. In addition, da'wah must also be based across disciplines using a variety of approaches, communication, psychology, and sociology. On this basis, preachers who are members of the PMD are given the training to develop their preaching abilities.

The success of da'wah is determined by how the da'wah is carried out, for example, the procedures for preaching, packaging material, attitudes and ways of preaching, ${ }^{46}$ media usage, and preaching_training. In pesantren, for example, preaching training is known as Muhadharah ${ }^{47}$ and khitabah training for students to form professional preachers cadres. ${ }^{48}$ _ The PMD provides training to the preachers periodically with the support of the local government. Of a large number of PMD preachers, they were classified into two training periods with a total of 70 preachers for preaching training.

Training is an important activity carried out to improve the ability of science in a planned and well programmed. Training is a short education for preachers to get additional skills regarding da'wah, including material, methods, use of facilities, and others. The importance of this training is part of the conditions of the technology community, who are very familiar with the technology. Therefore, each preacher is expected to be able to master the existing technical facilities as a means or medium for delivering messages. The use of IT is part of the effectiveness of preaching messages that can be received by all people at the same time and in different places so that preaching can be conveyed anytime, anywhere and to anyone.

Da'i training is conducted for the purpose of providing knowledge and skills in da'wah. If no training is included, the preachers in carrying out their da'wah seem to 'appear as they are.' The da' $i$ training is also carried out to familiarize the preachers to appear in front of the public. As a result, the training is needed in the face of a complex da'wah field. Knowledge and skills gained through training then become an essential capital of the preacher in preparing the preachers' da'wah.

Each preacher is classified according to the level of preaching ability, then given intensive training by senior preachers and mentors. The mentors were brought from higher education institutions of UIN Sultan Syarif Kasim Riau and UIN Imam Bonjol Padang. Da'i is also equipped with the ability to use IT in da'wah to add insight and material. To strengthen the training efforts for 
the da'í, several collaborations were made between the PMD and Radio Arrahman $102 \mathrm{Fm}$ and Dumai TV. For example, the collaboration was carried out by preachers doing live preaching on radio and Dumai TV.

The training for PMD preachers was carried out in response to the phenomenon of social change that was increasingly "suffocating." There are many changes that occurred due to the emergence of communication and information technology that sometimes surprised many people. As a result, it affects the governance of societies, as well as for the preachers who carry out their da'wah. Implementation of da'wah is required to "adjust" to the conditions of the congregation, both in terms of psychological and sociological.

No matter how perfect the material, if the da'wah does not place the media as the basis of the Da'wah movement, then it is certain that the da'wah will fail. Da'wah, without the media, seems ineffective and tends to be abandoned by the congregation. Therefore, the media plays an important role in every da'wah movement carried out, as stated by Marshall McLuhan, that the medium is the message. ${ }^{49}$ The PMD preachers preached through the media resulting from their collaboration, for example, on radio and TV. It will be developed on the internet and others. This fact is to answer the challenges of da'wah in the millennial era that led to what was expressed by McLuhan.

Various forms and ways of preaching in Islam indicate that the obligation to preach must also be adjusted to the abilities and expertise of each person. Everyone does not have to preach like a preacher because preaching can be done anywhere and by anyone. The most important thing is all done with the main goal, as stated through amar ma'ruf nahi munkar. ${ }^{50}$ The actualization of da'wah using the internet today has provided a new paradigm regarding the success of da'wah. The da'i is no longer a major factor of preaching because, in the context of a networked society, the mad'u does not only accept preaching messages passively. Instead, they actively process and interpret the messages they receive and are often not affected by the identity of the messenger. In the context of a networked society, there is no longer a preacher (author) or mad'u (reader) but merges in the same status, the user. ${ }^{51}$

As a result, it can be understood that the presence of internet access cannot be avoided because it has become a new civilization in the world of information and communication at a global level. With internet access, much information is feasible to be accessed by the public for personal interests, education, religion, business, and others. The mad'u who are internet users 
(users) not only look for information but with the information they get, they will share it again (reshare) through social media owned by adding other da'wah messages according to their appropriateness and understanding. ${ }^{52}$

\section{The Da'i Certification}

Certification for some people is a kind of giving certificates to preachers who meet the qualifications according to government or community organization standards as a sign that the person concerned has the eligibility to do da'wah. ${ }^{53}$ - This certification marks preachers as professional work that is measured according to Islamic institutional authority through the Indonesian Ulema Council and the Indonesian Ministry of Religious Affairs. For them, this certification is essential as a public demand related to comfort in the da'wah of Islam.

Professional enhancement of the PMD preachers is also carried out with the certification program. This certification is carried out in some stages to all preachers who are members of the PMD. The stages are processes to find, categorize, and classify the abilities possessed by each preacher so that with this classification, preachers can continue to improve their competence through formal and non-formal learning activities. The classification and level of ability do not intend to distinguish preachers but rather efforts to improve their professionalism.

In these processes, the preachers with good qualifications will be given an A with the location of the da' wah placed in large mosques and companies. B certification grade qualifications are placed in mosques, and small mosques are located in certain sub-district areas. C qualified preachers are placed in mosques and prayer rooms on the outskirts of the City. This was also done as an effort to motivate the preachers to continue to develop their preaching abilities so as to be able to improve their certification value qualifications in a better direction.

This certification process involves many parties, especially companies that provide accommodation, funds, and facilities. The company directly involved at the moment is Pertamina Dumai by providing accommodation in the form of lodging, transportation, and funding such as consumption and pocket money/honoraria. In addition, the educational institution selected is UIN Imam Bonjol Padang to be a certification team that assesses the quality and ability of the PMD preachers in preaching.

The certification team makes a competency assessment model that will 
be tested on preachers, in the form of compulsory material which is recommended to be mastered. The material being tested includes jurisprudence (without prioritizing the khilafiyah), monotheism, morals, worship, interpretation, hadith, muamalah, and general knowledge of Indonesia. Therefore, certification activities are a long process that must be passed by each preacher in the following standardization through pre-certification. Mastery of the material that is tested to each preacher is then a reason and answer for the preachers to get certified with ratings $A, B$, and $C$.

\section{Increased Education Level}

Education is one of the most important aspects of life. Education as a means to increase knowledge is an obligation for every Muslim. All activities carried out by humans are inseparable from the knowledge possessed, including da'wah activities. The quality of da'wah can be influenced by the educational status of a preacher. The higher the education level of the preacher, the better the preaching process will be carried out. Realizing this, the PMD City of Dumai made efforts to increase the professionalism of preachers.

The PMD, as an organization, has the duty to facilitate all preachers who want to continue their education to a higher level. The da' $i$ who have graduated from high school are facilitated to continue to undergraduate level, magistral level, and then to doctoral level. This is done because there are still many preachers of Dumai City who are still educated below the average of senior high school / Islamic boarding school. This is an important concern for the PMD to improve the scientific abilities of the preachers. Educational levels that are relatively in great demand are $\mathbf{S 1}$ (undergraduate) and S2 (master) in religious studies in several universities in Riau Province, such as UIN Sultan Syarif Kasim Riau, Riau Islamic University (UIR), STAl and others. Through the improvement of education levels, it is hoped that the preacher will be able to compete and answer the problems faced by the jama'ah when preaching is carried out.

In order to improve education, the PMD can collaborate with companies such as Pertamina in providing educational assistance (scholarships) to preachers who wish to continue their education. Scholarships are provided as a fund for semester tuition fees and daily needs. This level of education then also determines the competence and expertise in preaching activities. 


\section{Development of Contemporary Da'wah Material/Content}

In the process of da'wah, one of the crucial things is the da'wah material. The da'wah material delivered to the congregation must be appropriate material, and the current problems faced by the Muslim community in Dumai City. Da'wah material must be packaged as attractive as possible so that its values and meanings are received by the congregation well. In addition, the material must be adjusted to the ability of the congregation who receives the material. Therefore, preaching material is expected not to bore the congregation.

The preacher's profession, whose orientation is to communicate a number of religious messages to worshipers, must also adjust to social change. This certainly has an impact on the material that will be delivered to the congregation. In other words, a preacher must master the material preaching at the same time understanding the pilgrims, both in terms of psychological and sociological. The most important question of this issue is how the preacher's readiness in packaging the material for preaching and then communicate to the middle of the congregation. ${ }^{54}$

The importance of developing da' wah material is a necessity so that the preachers have a thorough preparation. ${ }^{55}$ The preachers at the PMD does the development of material with various methods such as book review, hadith, pointer making, and writing or preaching concepts. Material or content is significant as the primary substance in every preaching done. Therefore, it is necessary to develop material that is appropriate to the situation and needs of the people who will receive the messages of da'wah.

The effort made by the PMD is to prepare the most current and conditional preaching materials. The latest da'wah material is intended to answer the actual problems in the da'wah field encountered. Da'wah material developed by the PMD is in the form of Da'wah books that can be guided in Da'wah activities. The materials are collected according to the real conditions that occur in the community. Strengthening the material carried out by PMD is in the form of equipping the preachers. The PMD prepares the latest da'wah materials as the concept of da'wah for the preachers so that there is a uniformity of the preaching material delivered by the PMD preachers in each preaching activity.

The preachers were also asked to make various da'wah concepts, and selection would be conducted by the PMD. The good material with the best concept will be used as a topic of discussion in da'wah. This activity was 
carried out in collaboration with other Da'wah institutions and Da'wah experts in preparing the preachers for the continuity of the preaching material delivered to the Dumai community.

\section{CONCLUSION}

The development of preacher professionalism is an urgent need at a time when social change is increasingly 'pushed' to the surface. The rise of the crisis of human values, one of which is caused by the presence of technology, has resulted in the emergence of such complex social problems. To anticipate phenomena and the impact of the technology as well as to meet the challenges of an increasingly complex social change, the necessary da'wah professional movements are needed. Under such conditions, the PMD has tried to improve the professionalism of preachers in Dumai. This article does not study whether or not the efforts done by the PMD was successful. It only focuses on activities done by the PMD as a way to improve the professionalism of Muslim preachers in Dumai. In realizing professional preaching human resources, the PMD preachers are given several activities namely mudhakarah and religious dialogue as a form of da'wah guidance to strengthen the ability and skills of preachers; training and IT utilization activities are carried out to familiarize the preachers in preaching in public spaces and mastering the stage. Likewise, the presence of technology makes it easier for preachers to carry out their da'wah in accordance with the needs of the congregation. Preaching certification is conducted in an effort to assess and qualify the quality of preachers in accordance with the level decided. Training is done to improve the preachers' quality and their mastery of various fields; the increased levels of education among the PMD preachers is done through cooperation agreements with companies, universities, and government; and the development of contemporary da'wah material for the PMD preachers is done through the study of books, hadith and actual phenomena which are then evaluated periodically as a reference for preachers in da'wah.

This article provides an overview of the da'wah done in local Indonesia in Dumai. This study benefits for Islamic studies focusing on realistic da'wah, which is neglected by scholars. Several studies on da'wah mostly focus on normative aspects. This can be seen from some studies done by Zaini and Basit, for instance. They may contribute to Islamic studies in general. However, the focus on empirical research can be done for the specific benefits of Indonesian Islam. This will denote the significance of da'wah, which cannot 
be done in a monolithic way. Indonesian Islam requires multiple da'wah since da'wah in Indonesian Islam can be done based on the local context. This study then suggests that da'wah in Indonesia entails local culture to support the success of da'wah. Da'wah's studies on the local context need to be explored further so that they can contribute to Islamic studies, especially Indonesian Islam.

\section{ENDNOTES}

1 Aris Risdiana, "Transformasi Peran Da'i Dalam Menjawab Peluang Dan Tantangan (Studi terhadap Manajemen SDM),"Jumal Dakwah 15, no. 2 (2014): 433-51, https://doi.org/10.14421/jd.2014.\%x.

2 Julian Millie, "Spiritual Meal" or Ongoing Project? The Dilemma of Dakwah Oratory" in Greg Fealy and Sally White (Eds), Expressing Islam : Religious Life and Politics in Indonesia, Singapore: Institute of Southeast Asian Studies, 2008, pp. 80-94.

3 Risdiana.

4 Perdamaian Perdamaian, Kodarni Kodarni, dan Dony Arung Triantoro, "Strategi Dakwah Berbasis Media Elektronik Di Persatuan Mubaligh Dumai (PMD) Kota Dumai," Idarotuna 1, no. 1 (9 Oktober 2018), http://ejournal.uinsuska.ac.id/index.php/idarotuna/article/view/6071.

5 Risdiana, "Transformasi Peran Da'i Dalam Menjawab Peluang Dan Tantangan (Studi terhadap Manajemen SDM)."

6 Perdamaian, Kodarni, dan Triantoro, "Strategi Dakwah Berbasis Media Elektronik Di Persatuan Mubaligh Dumai (PMD) Kota Dumai.”

7 Fahrurrozi Fahrurrozi, "Sertifikasi atau Standarisasi Khatib? Respons Para Da'i di Kota Mataram," Jurnal Komunikasi Islam 8, no. 1 (1 Oktober 2018): 155-78, https://doi.org/10.15642/jki.2018.1.1.155-178.

8 Saipul Annur, "Respon Masyarakat Terhadap Sertifikasi Ulama Di Kota Palembang," Medina-Te/ : Jurnal Studi Islam 18, no. 1 (16 Juli 2018): 102-20.

9 Arsam Arsam, "Persepsi Para Mubaligh Terhadap Wacana Kontroversi Standardisasi Khatib Dan Sertifikasi Mubaligh," Komunika: Jurnal Dakwah Dan Komunikasi 11, no. 2 (2017): 235-49, https://doi.org/10.24090/ komunika.v11i2.1367.

10 Risdiana, "Transformasi Peran Da'i Dalam Menjawab Peluang Dan Tantangan (Studi terhadap Manajemen SDM)."

11 Perdamaian, Kodarni, dan Triantoro, "Strategi Dakwah Berbasis Media Elektronik Di Persatuan Mubaligh Dumai (PMD) Kota Dumai.”

12 Fahrurrozi, "Sertifikasi atau Standarisasi Khatib?"

13 Ahmad Zaini, "Dakwah melalui Televisi," At-Tabsyir: Jurnal Komunikasi Penyiaran Islam, Vol. 3 No.1 (Juni 2016), h. 1-20.

14 Abdul Basit, “Dakwah Cerdas di Era Modern” Jumal Komunikasi Islam, Vol. 3, No. 1 (2013), h. 76-94. 
15 Wawancara dengan Ketua PMD, Drs. H. Asyari, tanggal 8 Oktober 2018.

16 Nanang Martono, Sosiologi Perubahan Sosial, Jakarta : Rajawali Press, 2014, h.397

17 Abu Bakar Madani, "Dakwah Dan Perubahan Sosial: Studi Terhadap Peran Manusia Sebagai Khalifah Di Muka Bumi,” Lentera 1, no. 01 (18 Mei 2017), https://doi.org/10.21093/lentera.v1i01.851.

18 Madani

19 Efa Rubawati, "Media Baru: Tantangan Dan Peluang Dakwah," Jurnal Studi Komunikasi 2, no. 1 (1 Maret 2018), https://doi.org/10.25139/jsk.v2i1.586.

20 Rubawati.

21 Rubawati.

22 Asep Iwan Setiawan, "Dakwah Berbasis Pemberdayaan Ekonomi dan Peningkatan Kesejahteraan Mad'u," Ilmu Dakwah: Academic Journal for Homiletic Studies 6, no. 2 (2012): 347-262, https://doi.org/10.15575/idajhs.v6i2.342.

23 Madani, "Dakwah Dan Perubahan Sosial."

24 https://kbbi.web.id/profesional, 2019.

25 https://dictionary-cambridge-org.cdn.ampproject.org/v/s/ dictionary.cambridge.org/amp/english/professionalism?amp_js_v=a3\&...

26 https://www.merdeka.com., 23 Mei 2018.

27 https://www.merdeka.com., 23 Mei 2018 dan https://www.merdeka.com, 22 Mei 2018

28 Arsam, "Persepsi Para Mubaligh Terhadap Wacana Kontroversi Standardisasi Khatib Dan Sertifikasi Mubaligh."

29 Arsam.

30 Arsam.

31 republika.co.id, 26 Juli 2018; tribunnews.com/nasional 6 September 2018; dan cnnindonesia.com/nasional 3 September 2018.

32 Arsam.

33 Fahrurrozi, "Sertifikasi atau Standarisasi Khatib?"

34 Fahrurrozi.

35 Fahrurrozi.

36 UU No. 16 Tahun 1999 diakses melalui www.bpkp.go.id tanggal 6 September 2019.

37 Pulla Pandika Widodo dan Elisawati Elisawati, "Penjadwalan Mubaligh Online Pada Persatuan Mubaligh Dumai (PMD) Kota Dumai," I N F O R M A T I KA 9, no. 2 (10 Januari 2019): 25-32.

38 Perdamaian, Kodarni, dan Triantoro, "Strategi Dakwah Berbasis Media Elektronik Di Persatuan Mubaligh Dumai (PMD) Kota Dumai.”

39 Perdamaian, Kodarni, dan Triantoro.

40 Wahyu Budiantoro, "Urgensi Manajemen Dalam Pengembangan Aktivitas Dakwah," Komunika: Jurnal Dakwah dan Komunikasi 10, no. 2 (2016): 278-91, https://doi.org/10.24090/komunika.v10i2.949.

${ }^{41}$ Asep Shodiqin, "Reposisi Muballigh: Dari 'Personal' Menuju 'Agent of Change," Ilmu Dakwah: Academic Journal for Homiletic Studies 6, no. 2 (2012): 363-82, 
42

43 Widodo dan Elisawati, "Penjadwalan Mubaligh Online Pada Persatuan Mubaligh Dumai (PMD) Kota Dumai."

44 Budiantoro, "Urgensi Manajemen Dalam Pengembangan Aktivitas Dakwah."

45 Aliyudin Aliyudin, "Prinsip-prinsip Metode Dakwah menurut Al-Qur'an," Ilmu Dakwah: Academic Journal for Homiletic Studies 5, no. 15 (2010): 1007-22, https:/ /doi.org/10.15575/idajhs.v5i15.431.

46 Aliyudin.

47 Eko Stiawan, "Strategi Muhadharah Sebagai Metode Pelatihan Dakwah Bagi Kader Da'i Di Pesantren Daarul Fikri Malang," Fenomena 14, no. 2 (23 Maret 2016), http://ejournal.iain-jember.ac.id/index.php/fenomena/article/view/ 210.

48 Ainiatul Fuadiyah, "Manajemen Pelatihan Khitobah Dalam Meningkatkan Kemampuan Santri Menjadi Muballigh Profesional Di Pondok Pesantren Salaf Tahfidz Al-Qur'an Al Arifiyyah Pekalongan" (undergraduate, UIN Walisongo, 2015), http://eprints.walisongo.ac.id/4764/.

49 Ditha Prasanti, "Perubahan Media Komunikasi Dalam Pola Komunikasi Keluarga Di Era Digital,” Commed/ : Jurnal Komunikasi Dan Media 1, no. 1 (17 Juli 2017): 69-81.

50 Rubawati, "Media Baru."

51 Rubawati.

52 Rubawati.

53 Fahrurrozi, "Sertifikasi atau Standarisasi Khatib?"

54 Marhen Marhen, "Persiapan Mubaligh Dalam Mengemas Materi Tabligh," Alfuad: Jurnal Sosial Keagamaan 2, no. 1 (15 November 2018): 65-79, https:// doi.org/10.31958/alfuad.v2i1.1210.

55 Marhen.

\section{REFERENCES}

Aliyudin, Aliyudin. "Prinsip-prinsip Metode Dakwah menurut Al-Qur'an.” Ilmu Dakwah: Academic Journal for Homiletic Studies 5, no. 15 (2010): 1007-22. https:/ /doi.org/10.15575/idajhs.v5i15.431.

Annur, Saipul. "Respon Masyarakat Terhadap Sertifikasi Ulama Di Kota Palembang.” Medina-Te/ : Jurnal Studi Islam 18, no. 1 (16 Juli 2018): 102-20.

Arsam, Arsam. "Persepsi Para Mubaligh Terhadap Wacana Kontroversi Standardisasi Khatib Dan Sertifikasi Mubaligh." Komunika: Jurnal Da'wah Dan Komunikasi 11, no. 2 (2017): 235-49. https://doi.org/10.24090/ komunika.v11i2.1367.

Basit, Abdul ." Dakwah Cerdas di Era Modern” Jurnal Komunikasi Islam, Vol. 3, No. 1 (2013), h. 76-94.

Budiantoro, Wahyu. "Urgensi Manajemen Dalam Pengembangan Aktivitas Dakwah.” Komunika: Jurnal Da'wah dan Komunikasi 10, no. 2 (2016): 278-91. https://doi.org/10.24090/komunika.v10i2.949. 
Fahrurrozi, Fahrurrozi. "Sertifikasi atau Standarisasi Khatib? Respons Para Da'i di Kota Mataram.” Jurnal Komunikasi Islam 8, no. 1 (1 Oktober 2018): 155-78. https://doi.org/10.15642/jki.2018.1.1.155-178.

Fuadiyah, Ainiatul. "Manajemen Pelatihan Khitobah Dalam Meningkatkan Kemampuan Santri Menjadi Muballigh Profesional Di Pondok Pesantren Salaf Tahfidz Al-Qur'an Al Arifiyyah Pekalongan.” Undergraduate, UIN Walisongo, 2015. http://eprints.walisongo.ac.id/4764/.

Kholili, H. M. Kholili H. M. "Pondok Pesantren Dan Pengembangan Potensi Dakwah.” Jumal Dakwah 13, no. 2 (2012): 177-202. https://doi.org/10.14421/ jd.2012.\%x.

Kriyantono, Rachmat, Teknik Praktis Riset Komunikasi, Jakarta: Kencana, 2014.

Madani, Abu Bakar. "Dakwah Dan Perubahan Sosial: Studi Terhadap Peran Manusia Sebagai Khalifah Di Muka Bumi.” Lentera 1, no. 01 (18 Mei 2017). https://doi.org/10.21093/lentera.v1i01.851.

Marhen, Marhen. “Persiapan Mubaligh Dalam Mengemas Materi Tabligh.” Alfuad: Jurnal Sosial Keagamaan 2, no. 1 (15 November 2018): 65-79. https://doi.org/ 10.31958/alfuad.v2i1.1210.

Martono, Nanang. Sosiologi Perubahan Sosial, Jakarta : Rajawali Press, 2014.

Moleong, Lexy J., Metode Penelitian Kualitatif, Bandung: PT. Remaja Rosdakarya, 2000.

Nurfuadi, Nurfuadi. "Reaktualisasi Profesi Dakwah." Komunika: Jurnal Da'wah dan Komunikasi 2, no. 1 (2008): 54-72. https://doi.org/10.24090/komunika.v2i1.810.

Perdamaian, Perdamaian, Kodarni Kodarni, dan Dony Arung Triantoro. "Strategi Dakwah Berbasis Media Elektronik Di Persatuan Mubaligh Dumai (PMD) Kota Dumai." Idarotuna 1, no. 1 (9 Oktober 2018). http://ejournal.uin-suska.ac.id/ index.php/idarotuna/article/view/6071.

Prasanti, Ditha. "Perubahan Media Komunikasi Dalam Pola Komunikasi Keluarga Di Era Digital.” Commed/ : Jurnal Komunikasi Dan Media 1, no. 1 (17 Juli 2017): 69-81.

Risdiana, Aris. "Transformasi Peran Da'i Dalam Menjawab Peluang dan Tantangan (Studi terhadap Manajemen SDM).” Jurnal Dakwah 15, no. 2 (2014): 433-51. https://doi.org/10.14421/jd.2014.\%x.

Rubawati, Efa. "Media Baru: Tantangan dan Peluang Dakwah.” Jurnal Studi Komunikasi 2, no. 1 (1 Maret 2018). https://doi.org/10.25139/jsk.v2i1.586.

Setiawan, Asep Iwan. "Dakwah Berbasis Pemberdayaan Ekonomi dan Peningkatan Kesejahteraan Mad'u." Ilmu Da'wah: Academic Journal for Homiletic Studies 6, no. 2 (2012): 347-262. https://doi.org/10.15575/idajhs.v6i2.342.

Shodiqin, Asep. "Reposisi Muballigh: Dari 'Personal' Menuju 'Agent of Change." Ilmu Dakwah: Academic Journal for Homiletic Studies 6, no. 2 (2012): 363-82. https://doi.org/10.15575/idajhs.v6i2.343.

Stiawan, Eko. "Strategi Muhadharah Sebagai Metode Pelatihan Dakwah Bagi Kader Da'i Di Pesantren Daarul Fikri Malang." Fenomena 14, no. 2 (23 Maret 2016). http://ejournal.iain-jember.ac.id/index.php/fenomena/article/view/210. 
Widodo, Pulla Pandika, dan Elisawati Elisawati. "Penjadwalan Mubaligh Online Pada Persatuan Mubaligh Dumai (PMD) Kota Dumai." I N F O R M A T I KA 9, no. 2 (10 Januari 2019): 25-32.

Zaini, Ahmad. "Dakwah melalui Televisi," At-Tabsyir : Jurnal Komunikasi Penyiaran Islam, Vol. 3 No.1 (Juni 2016), h. 1-20.

https://dictionary-cambridge-org.cdn.ampproject.org/v/s/dictionary.cambridge.org/amp/ english/professionalism?amp_js_v $=\mathrm{a} 3 \&$...

http//www.republika.co.id, diakses pada 26 Juli 2018.

http//www.tribunnews.com/nasional, diakses pada 6 September 2018.

http//www.cnnindonesia.com/nasional, diakses pada 3 September 2018.

https://kbbi.web.id/profesional, diakses pada 2019.

https://www.pelajaran.id/2017/14/pengertian-profesionalitas-menurut-paraahli.html.

https://www.merdeka.com., diakses pada 23 Mei 2018.

https://www.merdeka.com, diakses pada 22 Mei 2018

UU No. 16 Tahun 1999 diakses melalui www.bpkp.go.id diakses pada 6 September 2019. 
